\title{
Successful Implementation of Pharmacy Retail Store Loyalty Reward Programs
}

\author{
Cristina D. Reinert \\ Saint Leo University \\ Jill A. Murray \\ Walden University and Lackawanna College
}

Loyalty reward programs are utilized within various industries as a key marketing strategy. A successfully implemented loyalty reward program benefits both the consumer and the company. The purpose of this multicase study was to explore strategies that pharmacy retail managers use to deliver loyalty reward programs. The theory of planned behavior was used as the conceptual framework to guide the study. Mobile technology, customer involvement, brand management, and tier-based rewards were the themes that emerged during data analysis. The findings are of interest to pharmacy retail managers and marketers because they are instrumental in implementing a successful loyalty reward program.

Keywords: customer, pharmacy retail store, loyalty program, mobile technology, reward program

\section{Introduction}

The U.S. pharmacy retail industry has more than $\$ 21$ million dollars in monthly sales revenue (U.S. Census Bureau, 2017). The retail, travel, and financial service industries within the United States spend more than $\$ 1$ billion annually on customer reward programs (Steinhoff \& Palmatier, 2016). A reward program is a marketing strategy that is used in the U.S. retail industry that aims to create a positive experience for the customer in exchange for their continued loyalty (Brakus, Schmitt, \& Zarantonello, 2009). The results of this study may increase pharmacy managers and marketers understanding of proven effective strategies when implementing a reward program as a marketing tool.

\section{Purpose}

To build a long-term relationship, companies implement reward programs as a strategy to attract, retain, and satisfy their customers while increasing their profitability (Gandomi \& Zolfaghari, 2013; Zhang \& Breugelmans, 2012). Sales can increase when the customer is correctly stimulated to participate in a reward program. Pharmacy chains can create and implement a reward program that increases brand perception and promotes brand loyalty. If customer satisfaction or loyalty is lacking, pharmacy chains may choose to include a reward program as a marketing strategy (Cant \& Toit, 2012). In this qualitative, multicase study, we explored the strategies that pharmacy retail store managers use to deliver successful customer reward programs. This study contains data gathered from managers at two successful retail pharmacy chains located in Florida. 


\section{Methodology}

The qualitative method was appropriate for this study because this design focuses on emotions instead of numbers (Leedy \& Ormrod, 2013) and is an effective way to examine customer desires (Barnham, 2012). Because we are exploring the managers' strategies and not the actual sales data, a qualitative method was the best choice.

The researcher chose a multicase study design for this research study. Case study is a commonly used qualitative research tradition (Hays \& Wood, 2011; Yin, 2014). A case study design explores a phenomenon that includes managerial and organizational practices with two or more data sources, and data collection consists of why and how questions (Yin, 2014).

\section{Population and Sampling}

The population sample consisted of two groups, one for each retail pharmacy located in Florida. Each group consisted of four managers; a store manager, pharmacy manager, assistant store manager, and marketing manager. Retail Pharmacy Chain A will include participants from Group A, and Retail Pharmacy Chain B will include participants from Group B. To target this specific population, purposive sampling per Robinson (2014) was used. Specifically, a typical case sampling with minimum criterion for quality assurance. Each participant met the following criteria: (a) employment by the selected retail pharmacy chain, (b) ability to participate in a face-to-face interview, and (c) having direct involvement with the formulation or delivery of, the store's loyalty reward program.

\section{Data Collection}

After Institutional Review Board approval, data collection occurred during the interviews and from the documents related to the reward program. The overarching research question used in this study was: What strategies do pharmacy retail store managers use to deliver loyalty reward programs? The interview questions were semistructured, open-ended questions (see Table 1). The interviews and reviews were done according to accepted interview procedures (Goulding, 2005; Yin, 2014). We audio recorded each interview with my iPhone audio recording application, in accordance with Englander's (2012) recommendation of audio recording and transcribing each interview for ease of analysis. The interviews were transcribed and member checks were performed to confirm data accuracy. Collected data was evaluated and organized into themes using Microsoft Excel. 
Table 1.Interview Protocol Questions

\begin{tabular}{ll}
\hline Number & Question \\
\hline 1 & $\begin{array}{c}\text { What strategies have you implemented at the pharmacy retail store that } \\
\text { have been successful in promoting your loyalty reward program? } \\
\text { What strategies are used in your loyalty reward program that increase } \\
\text { customer participation? }\end{array}$ \\
3 & $\begin{array}{c}\text { What strategies are used in your loyalty reward program that increase } \\
\text { store revenue? }\end{array}$ \\
& $\begin{array}{c}\text { What strategies are used in your loyalty reward program that increase } \\
\text { specific product sales? }\end{array}$ \\
& What strategies are used in your loyalty reward program that include \\
& technology?
\end{tabular}

\section{Reliability and Validity}

Goulding (2005) found that when specific methods and parameters are followed and could be replicated, then the qualitative research is considered reliable. Yin's (2011) five phases of analysis were used in this study. Triangulation of multiple data sources increases reliability of the study (Denzin, 2012). To achieve this, we used the interviews, collected documents, and the retail pharmacy websites. Upon completion of data collection, we sorted the data using triangulation to find emerging themes, as suggested by Yin (2014). The participant interviews were transcribed for analysis. We looked for general meanings to create brackets of interpretation (St. Pierre \& Jackson, 2014). We achieved data saturation within this study because there was no new information available from the collected data and analysis.

\section{Limitations}

Limitations may affect the methodology and analysis of a research study and are beyond the control of the researcher (Leedy \& Ormrod, 2013). The following are the identified limitations of this study. First, quantitative metrics were not used to validate the results. Second, only two locations in Florida with a limited number of participants were studied. This may not be a good representation of retail pharmacy chains across the United States. Finally, participants may have withheld information for privacy concerns or unknowingly lacked valuable data on all marketing strategies in place at the retail pharmacy.

\section{Conceptual Framework}

The chosen theory for this study was the theory of planned behavior (TPB). Icek Ajzen developed the TPB in 1985 as a model for predicting human social behavior (Ajzen, 2011). The model for this theory consists of five elements: (a) attitude toward the behavior, (b) subjective norm, (c) perceived behavioral control, (d) intention and (e) behavior. These elements are jointly dependent upon the intention and behavioral control to achieve a desired end behavior (Ajzen, 1991). According to the TPB, the intentions of the customer can be seen through motivational factors that influence their behavior (Ajzen, 1991). 


\section{Review of the Literature}

My review of prior literature on customer loyalty, the retail industry, and marketing strategies revealed the vastness of the retail industry. This review identified a gap in the literature on the development and implementation of successful reward programs in the pharmacy retail industry. The review of the literature is organized according to the TPB model's five elements.

\section{Attitude Toward the Behavior}

The attitude a customer holds toward a specific brand can affect their buying patterns of that brand or product (Anilkumar \& Joseph, 2012). Positive communication between the brand and the customer are factors for growth and increased revenue (Day \& Moorman, 2013). Growth cannot occur without positive customer satisfaction (Nazari, Divkolaei, \& Sorkhi, 2012). The pharmacy retail industry can promote positive attitudes with an effective reward program. Satisfied customers are more likely to participate and benefit from a reward program. A satisfied customer typically views a reward program with a positive attitude, and an unsatisfied customer will view a reward program with a negative attitude (Gandomi \& Zolfaghari, 2013). A satisfied customer that utilizes a reward program will become or remain loyal to the brand through a long-term relationship (Kang, Alejandro, \& Groza, 2014).

A successfully implemented reward program will increase customer purchases (Bahri-Ammari, 2012). Pharmacy store managers and marketers can also influence a positive outcome for their stores by highlighting reward program benefits to the customer face to face. A customer reward card is a relationship management tool that should be used as a part of the marketing strategy for the company (Acatrinei \& Puiu, 2012). The anticipated value of a reward program to the pharmacy store is not just increased profits, but increased loyalty for long-term relationship benefits. The operating costs of the reward program should be outweighed by the anticipated long-term profits of satisfied customers. A lack of customer satisfaction may negatively affect the customer relationship process for the short and long-term (Gocek \& Beceren, 2012). In the United States, customer loyalty and reward programs have more than 1.3 billion members (Khan, 2014). This number is expected to increase annually by approximately 11\% (Evanschitzky et al., 2012). The high rate of acceptance by U.S. customers should be encouraging to retail companies that offer or are considering a reward program. Reward programs are an effective tool to gather large amounts of customer data with the potential to create business growth (Acatrinei \& Puiu, 2012).

\section{Subjective Norm}

A better understanding of customer involvement, social motivations, and commitment will provide managers and marketing professionals a chance to improve and implement a successful reward program. Technology and social media have become key components in the development of positive brand image (Furlow, 2011). Customers that are socially motivated create a community amongst themselves that can forge a positive image of the desired brand. The increase in the use of technology, specifically mobile technology has opened new strategies for the retail industry to create and grow customer loyalty.

The Internet has shifted control from the business over to the customer, which may or may not always be beneficial for the company (Berthon, Pitt, Plangger, \& Shapiro, 2012). Digital media has proven to be more efficient than other available broadcast mediums (Fulgoni \& Lipsman, 2015). The expansion of customer communication and networking has altered how companies can and should interact with their customers on a daily basis. The use of the Internet in a reward program can be beneficial access for the customer to learn, join, and use the program benefits. Increased customer 
satisfaction should be a top priority within a business marketing strategy (Gocek \& Beceren, 2012). Any retail establishment can use the Internet to build a positive customer relationship (Gocek \& Beceren, 2012).

Researchers can use social media sites to explore, inform, and question various forms of data (Fielding, 2014). Social media provides customers with a global stage to broadcast their approval or disapproval of a brand (Berthon et al., 2012). A dissatisfied customer may use social media or the Internet to share their negative experience with a brand or company, which may have a long-term negative impact (Gocek \& Beceren, 2012). The high rate of social media usage by customers has forced companies to become creative and more direct in their marketing efforts (Kumar, 2015). Social media is a valuable customer touch point. Used correctly, social media will produce customer data that can be used by managers and marketers to conduct research (Nunan \& Yenicioglu, 2013).

\section{Perception}

Perceived behavior control specifically refers to the person's perception of ease or difficulty when performing a specific behavior (Ajzen, 1991). This perception is why managers and marketers should consider their customers' needs when creating a reward program. The customer perceived value is directly related to their satisfaction (Malik, 2012). A reward program can provide the customer with a positive perceived value from the brand or business (Meyer-Waarden, 2015). Direct marketing of targeted coupon promotions can give the customer a feeling of value and appreciation from the brand or business (Venkatesan \& Farris, 2012). A customer that participates in a reward program benefits from the rewards, and the business benefits from the customers continued loyalty and data collection (Cant \& Toit, 2012). A reward program can encourage new customer's participation and retain existing customer's loyalty. Reward programs are only as successful as the customer has perceived the value to be (Khan, 2014).

Brand image is a valuable asset formed through the relationship of a company and its customer. Most customers make purchasing decisions based on product availability and brand image (Anilkumar \& Joseph, 2012). The image of a retail establishment should align with the customer expectation and previous experience (Gocek \& Beceren, 2012). Price can be a vital component of the marketing strategy in a retail pharmacy. Brand image can directly tie into customer perceptions of value with high or low prices (Hamilton \& Chernev, 2013). A business should already have a pricing strategy in place before embarking on a brand image. The ability to change a customer perceived brand image is a challenging and typically unsuccessful task.

Marketing strategies not only involve the product and the service, but also include the customer experience (Malik, 2012). The customer experience and expectations should be considered as one part of the strategy when implementing a successful reward program. A reward program that is properly implemented, maintained, and monitored could retain customer loyalty. The brand experience is the whole customer experience at every touch point associated with the retail store brand (Shamim \& Muhammad, 2013). Through brand management and customer monitoring, the retail company can achieve brand loyalty and positive brand experience (Anilkumar \& Joseph, 2012).

\section{Intention}

Strong brands built through targeted marketing promotes a bond between the customer and the brand (Luxton, Reid, \& Mavondo, 2015). Many customers shop at a pharmacy retail store to serve their needs, however, may choose a specific pharmacy retail store over another when they have an emotional-based need (Evanschitzky et al., 2012). A customer's natural desire to feel valued should be the core strategy when a reward program is being designed (Arbore \& Estes, 2013). Reward 
programs offer two types of benefits to the customer, hard benefits and soft benefits (Arbore \& Estes, 2013). Hard benefits are tangible rewards, such as coupons, points, or cash back. Soft benefits are feeling rewards, such as the customer experience or sense of belonging with the brand.

Customer touch points are of vital importance to a retail pharmacy chain. The retail pharmacy may intend on creating one image, however, if their employees do not portray that image to the customer during interaction, the positive image will become tarnished. Competition has over saturated the retail industry in the United States (Lang \& Hooker, 2013). Creative brand management can create brand differentiation for the customer (Anilkumar \& Joseph, 2012). Businesses can use customer data to monitor customer-purchasing patterns, credit card transactions, and repeat customers (McQuilkin, 2013). Customers that know a brand by name highlights a known brand with a preconceived perception (Dabija, 2011).

\section{Behavior}

To achieve the desired behavior from the customer, both intention and behavioral control must be present (Ajzen, 1991). Customer loyalty forms through the relationship between the brand and the customer, not just the reward offered. For a successful reward program, certain psychological factors should be included (Henderson, Beck, \& Palmatier, 2011). If a customer frequents a specific retail location without a known reason, this is a psychological connection. Reward programs have increased in popularity with businesses and customers. In some instances, a business could increase their profits by 100\% with a customer reward program (Valenzuela, 2012). Habit-based reward programs can be very efficient in driving customer behavior (Henderson et al., 2011). Understanding customer behavior is beneficial to the retail pharmacy. Customer loyalty may hinge upon specific desired behaviors or simply convenience. If convenience is the driver behind customer loyalty, a reward program could encourage additional spending more often.

A properly implemented reward program can manipulate customer behavior (Choi \& Kim, 2013). A reward program rewards the customer for making purchases at a specific location. In some instances, a reward program works in conjunction with a VIP program or tier-based program (Garcia Gomez, Guitierrez Arranz, \& Gutierrez Cillan, 2012). A tier-based program provides larger rewards according to a pyramid type format. For example, a customer spends $\$ 100$ and earns 1 point per dollar spent, the more they spend is directly related to the number of points earned. By spending a certain amount each month, may place that customer in a specific reward program over customers that do not spend as much each month. Higher dollar amounts spent equates to a more prestigious reward program and sense of belonging.

A reward program is considered successful if the results hit the desired outcomes and are measurable (Bojei, Julian, Wel, \& Ahmed, 2013). Positive service quality received by the customer can create confidence and loyalty to the retail brand (Rishi \& Singh, 2012). Customer satisfaction is a part of the brand experience that can create loyalty and a long-term relationship between brand and customer (Gocek \& Beceren, 2012). A satisfied customer may utilize word-of-mouth (WOM) to share their experience. Positive WOM can attract new customers (Chan, Lin, \& Bodhi, 2014). WOM can either hurt or help a brand (Lovett, Peres, \& Shachar, 2013). Positive WOM is one of the highest compliments a brand can receive from their customer. 


\section{Research Findings}

The findings of this multicase study may be of interest to managers in retail and at corporate levels that currently have a customer reward program or are considering implementing one, specifically managers in the pharmacy retail industry. Many strategies are used when delivering a loyalty reward program. The variations in strategy depend upon the goals of the company and the purpose of the reward program. In both cases, more than one strategy was used simultaneously with the reward program to promote customer participation and maximize benefits for the company.

\section{Case 1: Group A}

The managers for Case 1 Group A believe having a reward of value to the customer is an important part of the program being successful at their store. The reward offered by Case 1 Group A is cash back based on the customer's daily purchases. This type of monetary reward is believed to be of value to customers. A monetary reward could exceed customer loyalty for the company, and instead promote loyalty to the reward (Meyer-Waarden, 2015). Customer participation increases when the customer realizes they are earning cash back into their wallets as opposed to just coupons, stated participant A4. A reward that is meaningful to the customer can encourage regular participation (Meyer-Waarden, 2015).

In addition to the reward, Case 1 uses mobile technology as a primary strategy. Group A participants found that customer participation increased with the use of mobile technology. The culture in the United States is very centered on technology, specifically mobile technology (Lawson, 2013). The use of a smartphone provides the customer with immediate access to earned rewards and promotes a positive experience. All of the managers found the combination of mobile technology and a cash back reward to be the driving force behind the success of their company's reward program. According to participant A4, technology is the backbone of our reward program, and probably any successful reward program offered. Case 1's use of mobile technology in their reward program includes the Internet, smartphones, and data tracking capabilities.

Coupons that are targeted directly to the customer based on purchasing patterns is the third strategy used by Case 1. Management believe the most effective method to increase store revenue is through targeted promotions that will move specific product from the store. To achieve this, bonus rewards and coupons are offered to the customer. According to all of the participants, the option for the customer to use their cash back in store also increases store revenue while rewarding the customer for their continued loyalty at that store.

\section{Case 2: Group B}

Case 2's reward program provides a point earning system on specialty products, members living healthy lifestyles, everyday items, and featured items. The managers agreed that reminding customers to use their loyalty card was a key strategy. Reminding the customers as well as the pharmacy and store staff to re-promote the loyalty card and its benefit are a part of the agenda for this pharmacy retail chain. Interacting with the customers daily, and using that time to remind and explain the benefits of the loyalty card is a proven strategy for these managers. Using customer specific coupons and weekly promotions, specifically in the beauty department, allow the reward program to push specific products to the customer. The consensus of the managers was their success was through the targeted marketing and personalized coupons offered through the customer use of the loyalty card. 
Positive store revenue is at the heart of company goals and a major goal for any loyalty program that is implemented. All participants jointly believe that for their company, the increase in store revenue is the benchmark in which they measure their loyalty cards success. Through point accumulation, special promotions, and time specific promotions the loyalty card will increase individual store revenue and overall company profits.

Technology can be seen in loyalty programs across the United States (Lawson, 2013). The loyalty card can be used via the customer's smartphone and through Apple Pay on the iPhone. This type of technology allows convenience for the customer and the ability to track data by the company. Managers believe that the inclusion of technology, specifically mobile technology is a proven strategy that drives customer participation.

\section{Analysis}

Four themes emerged from my data analysis and we have aligned those themes with the interview questions, the framework, and the literature we found on customer loyalty, pharmacy retail, and marketing. The themes were (a) mobile technology, (b) customer involvement, (c) brand management, and (d) tier-based rewards.

\section{Mobile Technology}

The theme mobile technology tied into the elements of subjective norm and perceived behavioral control. The theme emerged in the literature, the interviews, and the documents collected. Mobile technology that includes shopping applications for smartphones can increase customer participation and sales (Lawson, 2013). The participants discussed the importance of the smartphone app in the success of the reward program. The smartphone app provides the customer with immediate access to their reward account, coupons, and program information. Mobile technology is the primary touchpoint for the customer and the reward program. The customer receives personalized marketing efforts and rewards for continued loyalty.

Mobile technology with a smartphone app provides the pharmacy retail corporate managers access to real data in real time. The ability to track customer purchases and spending allows the reward program to be customized to each of the customers shopping patterns. The personalization of the reward program promotes loyalty, repeat purchases, and participation by the customer. The introduction between technology and the customer begins upon enrollment in the reward program. The customer can enroll with the cashier at check-out or online. Once enrollment is complete, the customer can begin accumulating rewards.

\section{Customer Involvement}

The theme customer involvement tied into the elements of attitude toward the behavior, intention, and behavior. The theme emerged primarily from the participants and the documents collected. The attitude toward the behavior that the retail pharmacy chain stores in Florida aim to create are a positive interaction between the brand and the customer. The literature that we found varied in customer involvement or engagement when participating in a reward program. Customer involvement can be encouraged through a positive brand experience and brand attitude (Shamim \& Muhammad, 2013). Participants from Group A and Group B regularly encourage their customers to use the smartphone app when participating in the reward program, and show them how they will benefit from this part of the program. Many customers do join reward programs; however, fail to use their rewards before they expire (Gandomi \& Zolfaghari, 2013). Participants from both retail pharmacy groups and the documents collected described a time limitation where rewards become 
void if not used, or the reward card goes unused for a period longer than 6 months. Participants from Group B believed that by reminding the customer to earn their points towards rewards, the customer would become more involved in the program and therefore become more loyal to the retail pharmacy.

\section{Brand Management}

The theme brand management tied into the elements of subjective norm, perceived behavioral control, and intention. The theme emerged from the literature and the documents collected. Within the retail industry there is a high level of competition (Lang \& Hooker, 2013). The retail pharmacy attempts to manage their brand through a reward program that collects data on the customer, provides bonus points for purchasing specific products within the store, and directly marketing to the customers that participate select coupons or offers based on their purchasing habits. When retailers use direct marketing that is attainable and measurable to the customer, sales can increase (Lund \& Marinova, 2015). The use of these marketing tools allows the retail pharmacy managers to remain consistent across all customer touchpoints. According to Participant B1, management works to reach the customer through positive touchpoints. Customer touchpoints are any point of contact the customer has with the brand either directly or indirectly that can affect their overall experience and attitude.

\section{Tier-Based Rewards}

The theme tier-based rewards tied into the elements of intention and behavior. The theme emerged in the literature and during data collection. The intention of the retail pharmacy chain is to track purchases, track spending, increase customer participation, target specific coupons and there use, target specific products, and directly market to the customer. Most customers have a natural desire to want to feel valued by others, specifically brands they are loyal to (Arbore \& Estes, 2013). A reward program with a value system that increases the reward for participation can create a feeling of value for the customer. Both retail pharmacies in this study have a tier-based reward system for their reward program. Tier-based rewards can promote a feeling of value for the customer (Arbore \& Estes, 2013). The more the customer purchases, specifically of bonus reward products, the more money they can earn in return. A reward program is typically comprised of two types of benefits, tangible or feeling rewards (Arbore \& Estes, 2013). The reward programs offered by both retail pharmacies in this study are tangible in nature with the hope that positive feelings will be cultivated for the customers. In addition to cash back earned, the customer also receives targeted coupons based on their shopping habits at the retail pharmacy.

\section{Implications and Recommendations}

The implications for managers and marketers of retail pharmacy chains may vary depending upon the type of loyalty reward program being implemented and the geographic location of the chain. The pharmacy retail chains in this study utilize a tier-based reward system with personal technology and are in Florida. Mobile technologies may create competitive advantages for the retail chains and a direct customer benefit. Technology interfaces and initiatives can be personalized for the retail chain and their target customer. The high failure rate of many reward programs is caused by mismanagement of the customer data (Luxton et al., 2015; Zhang \& Breugelmans, 2012). Mobile technology provides the retail pharmacy chain with direct customer sales data. Improved strategies and accurate collection of sales data could minimize the high percent of failure for these programs (Zhang \& Breugelmans, 2012). The sales data collected through a customer reward program can assist managers in personalizing the program to their customers (Nazari et al., 2012). Moving forward, managers and marketers may need to embrace new forms of technology to remain competitive with a reward program. A reward program that provides positive incentives, technology, 
perceived value, and savings to the customer can provide impactful results for the marketing managers (Kang et al., 2014).

A reward of value that can benefit the customer is a method used to promote and implement a successful reward program. If the earned reward is of higher value than the brand, some customers will only participate to obtain the reward (Meyer-Waarden, 2015). Discounts, savings, and cash back rewards from the company or through outside vendors may influence the customer to sign up and participate with the reward program. The retail pharmacy chains in this study have found success by offering all three to their customers. Cultural influence and economic factors can affect a customer's response to various marketing strategies (Petersen, Kushwaha, \& Kumar, 2015). Retail managers and marketers may be causing loyalty to the reward, not the retail brand itself.

Based on the research findings and themes, we recommend the following to retail pharmacy managers and marketers. First, technology may be beneficial to a reward program. Technology can track customer purchase and spending patterns, track specific product movement, and to distribute direct marketing coupons and rewards to the customer. Technology in a reward program should include smartphone apps, the Internet, social media, and data research or collection. Mobile technology may provide the customer with immediate access, information, and reward status.

Second, the reward offered to customers for participation and continued loyalty should be of value to the customer. Based on the findings provided in this study, cash back rewards are successful in creating customer participation and a perceived loyalty. The overall earned rewards can affect the customer's opinion and experience with the company. When this experience is positive, the customer is more likely to share this positive experience via WOM marketing (Ahrens, Coyle, \& Strahilevitz, 2013). The customers should also be able to accurately measure and predict their anticipated rewards. Customer experience and social influence can gauge the overall attitude of the customer toward a company (Anilkumar \& Joseph, 2012).

\section{Conclusions}

The purpose of this qualitative multicase study was to explore strategies used in pharmacy retail stores to deliver successful customer reward programs. The findings of this study correspond to the literature on customer loyalty and reward programs. The findings of this study may help managers and marketers in the pharmacy retail industry develop and implement a successful customer reward program. For a successful reward program, managers and marketers at the pharmacy retail store should have knowledge of their customer and the goals of the company. Reward programs encourage customer participation and loyalty through technology and customer touch points.

\section{References}

Acatrinei, C., \& Puiu, T. V. (2012). The loyalty card: Issues in evaluating loyalty program effectiveness. The International Journal of Economic Practices and Theories, 2, 153-164.

Ahrens, J., Coyle, J. R., \& Strahilevitz, M. A. (2013). Electronic word of mouth: The effects of incentives on e-referrals by senders and receivers. European Journal of Marketing, 47, 10341051. doi:10.1108/03090561311324192

Ajzen, I. (1991). The theory of planned behavior. Organizational Behavior and Human Decision Processes, 50, 179-211. doi:10.1016/0749-5978(91)90020-T 
Ajzen, I. (2011). Theory of planned behavior: Reactions and reflections. Psychology and Health, 26, 1113-1127. doi:10.1080/08870446.2011.613995

Anilkumar, N., \& Joseph, J. (2012). Factors influencing the pre-purchase attitude of consumers: A study. The IUP Journal of Management, 11, 23-53.

Arbore, A., \& Estes, Z. (2013). Loyalty program structure and consumers' perceptions of status: Feeling special in a grocery store? Journal of Retailing and Consumer Services, 20, 439-444. doi:10.1016/j.jretconser.2013.03.002

Bahri-Ammari, N. (2012). The effects of loyalty program quality on word-of-mouth recommendations intentions. World Academy of Science, Engineering, and Technology, 4, 826-835.

Barnham, C. (2012). Consumer reality. International Journal of Market Research, 54, 485-502. doi:10.2501/IJMR-54-4-485-502

Berthon, P. R., Pitt, L. F., Plangger, K., \& Shapiro, D. (2012). Marketing meets Web 2.0, social media, and creative consumers: Implications for international marketing strategy. Business Horizons, 55, 261-271. doi:10.1016/j.bushor.2012.01.007

Bojei, J., Julian, C. C., Wel, C., \& Ahmed, Z. U. (2013). The empirical link between relationship marketing tools and consumer retention in retail marketing. Journal of Consumer Behaviour, 12, 171-181. doi:10.1002/cb.1408

Brakus, J., Schmitt, B., \& Zarantonello, L. (2009). Brand experience: What is it? How is it measured? Does it affect loyalty? Journal of Marketing, 73, 52-68. doi:10.1509/jmkg.73.3.52

Cant, M. C., \& Toit, M. D. (2012). Identifying the factors that influence retail customer loyalty and capitalizing them. The International Business \& Economics Research Journal, 11, 12231232 .

Chan, S., Lin, T., \& Bodhi, P. (2014). Exploring the persuasive effect of member-get-member referral programs. Social Behavior and Personality, 42, 891-902. doi:10.2224/sbp.2014.42.6.891

Choi, S., \& Kim, S. (2013). Effects of a reward program on inducing desirable customer behaviors: The role of purchase purpose, reward type and reward redemption timing. International Journal of Hospitality Management, 32, 237-244.

Dabija, D. (2011). Empirical research on brand awareness in grocery retailing. Review of Economic Studies and Research Virgil Madgearu, 4, 21-36.

Day, G., \& Moorman, C. (2013). Regaining customer relevance: The outside-in turnaround. Strategy and Leadership, 41, 17-23. doi:10.1108/SL-04-2013-0021

Denzin, N. K. (2012). Triangulation 2.0. Journal of Mixed Methods Research, 6, 80-88. doi:10.1177/1558689812437156

Englander, M. (2012). The interview: Data collection in descriptive phenomenological human scientific research. Journal of Phenomenological Psychology, 43, 13-35. doi:10.1163/156916212X632943

Evanschitzky, H., Ramaseshan, B., Woisetschlager, M. D., Richelsen, V., Blut, M., \& Backhaus, C. (2012). Consequences of customer loyalty to the loyalty program and to the company. Academy of Marketing Science Journal, 40, 625-638. doi:10.1007/s11747-011-0272-3

Fielding, N. G. (2014). Qualitative research and our digital futures. Qualitative Inquiry, 20, 10641073. doi:10.1177/1077800414545237 
Fulgoni, G. M., \& Lipsman, A. (2015). Digital word of mouth and its offline amplification. Journal of Advertising Research, 55, 18-21. doi:10.2501/JAR-55-1-018-021

Furlow, N. (2011). Find us on Facebook: How cause marketing has embraced social media. Journal of Marketing Development \& Competitiveness, 5, 61-64.

Gandomi, A., \& Zolfaghari, S. (2013). Profitability of loyalty rewards programs: An analytical investigation. The International Journal of Management Science, 41, 797-807. doi:10.1016/j.omega.2012.10.003

Garcia Gomez, B., Guitierrez Arranz, A., \& Gutierrez Cillan, J. (2012). Exploring the influence of three types of grocery retailer loyalty programs on customer affective loyalty. International Review of Retail Distribution and Consumer Research, 22, 547-561. doi:10.1080/09593969.2012.711254

Gocek, I., \& Beceren, I. Y. (2012). Assessment of the effects of store image, perceived risk and customer relations on customer satisfaction in the textile industry. International Journal of Business and Social Science, 3, 133-145.

Goulding, C. (2005). Grounded theory, ethnography and phenomenology: A comparative analysis of three qualitative strategies for marketing research. European Journal of Marketing, 39, 294308. doi:10.1108/03090560510581782

Hamilton, R., \& Chernev, A. (2013). Low prices are just the beginning: Price image in retail management. Journal of Marketing, 77, 1-20. doi:10.1509/jm.08.0204

Hays, D. G., \& Wood, C. (2011). Infusing qualitative traditions in counseling research designs. Journal of Counseling and Development, 89, 288-295. doi:10.1002/j.15566678.2011.tb00091.x

Henderson, C. M., Beck, J. T., \& Palmatier, R. W. (2011). Review of the theoretical underpinnings of loyalty programs. Journal of Consumer Psychology, 21, 256-276. doi:10.1016/j.jcps.2011.02.007

Kang, J., Alejandro, T. B., \& Groza, M. D. (2014). Customer-company identification and the effectiveness of loyalty programs. Journal of Business Research, 68, 464-471. doi:10.1016/j.jbusres.2014.06.002

Khan, M. T. (2014). Customer loyalty programs-concept, types, goals and benefits (a conceptual and review paper). International Journal of Information, Business \& Management, 6, 74-93.

Kumar, V. (2015). Evolution of marketing as a discipline: What has happened and what to look out for. Journal of Marketing, 79, 1-9. doi:10.1509/jm.79.1.1

Lang, M., \& Hooker, N. H. (2013). An empirical test of experiential shopping in food retailing. British Food Journal, 115, 639-652. doi:10.1108/00070701311331553

Lawson, A. (2013, July 12). Analysis: Retailers battle for online grocery market share. Retail Week. Retrieved from http://www.retail-week.com/sectors/grocery/analysis-retailers-battle-foronline-grocery-market-share/5050863.article

Leedy, P. D., \& Ormrod, J. E. (2013). Practical research: Planning and design (10th ed.). Upper Saddle River, NJ: Pearson Education.

Lovett, M. J., Peres, R., \& Shachar, R. (2013). On brands and word of mouth. Journal of Marketing Research, 50, 427-444. doi:10.1509/jmr.11.0458 
Lund, D. J., \& Marinova, D. (2015). Managing revenue across retail channels: The interplay of service performance and direct marketing. Journal of Marketing, 78, 99-118. doi:10.1509/jm.13.0220

Luxton, S., Reid, M., \& Mavondo, F. (2015). Integrated marketing communication capability and brand performance. Journal of Advertising, 44, 37-46. doi:10.1080/00913367.2014.934938

Malik, S. U. (2012). Customer satisfaction, perceived service quality and mediating role of perceived value. International Journal of Marketing Studies, 4, 68-76. doi:10.5539/ijms.v4nlp68

McQuilkin, A. (2013). Reinventing retail. Display \& Design Ideas, 25, 72.

Meyer-Waarden, L. (2015). Effects of loyalty program rewards on store loyalty. Journal of Retailing and Consumer Services, 24, 22-32. doi:10.1016/j.jretconser.2015.01.001

Nazari, M., Divkolaei, Q. M., \& Sorkhi, B. M. (2012). Prioritizing the effective factors to customers' satisfaction. International Journal of Business and Management, 7, 236-242. doi:10.5539/ijbm.v7n2p236

Nunan, D. \& Yenicioglu, B. (2013). Informed, uninformed and participative consent in social media research. International Journal of Market Research, 55, 791-808. doi:10.2501/IJMR-2013-067

Petersen, J. A., Kushwaha, T., \& Kumar, V. (2015). Marketing communication strategies and consumer financial decision making: The role of national culture. Journal of Marketing, 79, 44-63. doi:10.1509/jm.13.0479

Rishi, B., \& Singh, H. (2012). Determinants of supermarket shopping behavior in an emerging market. Journal of Business \& Retail Management Research, 7, 27-38.

Robinson, O. C. (2014). Sampling in interview-based qualitative research: A theoretical and practical guide. Qualitative Research in Psychology, 11, 25-41. doi:10.1080/14780887.2013.801543

Shamim, A., \& Muhammad, M.B. (2013). A critical model of brand experience consequences. Asia Pacific Journal of Marketing and Logistics, 25, 102-117. doi:10.1108/13555851311290957

Steinhoff, L., \& Palmatier, R. W. (2016). Understanding loyalty program effectiveness: managing target and bystander effects. Journal of the Academy of Marketing Science, 44, 88-107. doi:10.1007/s11747-014-0405-6

St. Pierre, E. A., \& Jackson, A. Y. (2014). Qualitative data analysis after coding. Qualitative Inquiry, 20, 715-719. doi:10.1177/1077800414532435

U.S. Census Bureau. (2017). The 2017 annual monthly retail sales report. Retrieved from http://www.census.gov/retail

Valenzuela, F. R. (2012). The effect of switching barriers types on customer loyalty. International Review of Business Research Papers, 8, 1-19.

Venkatesan, R., \& Farris, P. (2012). Measuring and managing returns from retailer-customized coupon campaigns. Journal of Marketing, 76, 76-94. doi:10.1509/jm.10.0162

Yin, R. K. (2011). Qualitative research from start to finish (3rd ed.). Thousand Oaks, CA: Sage.

Yin, R. K. (2014). Case study research: Design and methods (5th ed.). Thousand Oaks, CA: Sage.

Zhang, J., \& Breugelmans, E. (2012). The impact of an item-based loyalty program on consumer purchase behavior. Journal of Marketing Research, 49, 50-65. doi:10.1509/jmr.09.0211 
The International Journal of Applied Management and Technology (IJAMT), sponsored by Walden University's School of Management, is a peer-reviewed, online journal that addresses contemporary national and international issues related to management and technology. The objectives of the IJAMT are to: (a) encourage collaborative and multi-disciplinary examinations of important issues in business and technology management, and (B) engage scholars and scholar-practitioners in a dynamic and important dialogue.

Walden University Publishing: http://www.publishing.waldenu.edu 